\title{
PENERAPAN SKEPTISISME PROFESIONAL AUDITOR INTERNAL PEMERINTAH DALAM MENDETEKSI KECURANGAN (Studi Kasus pada Auditor Perwakilan BPKP Provinsi Jawa Tengah)
}

\author{
Sarina Gabryela Aprilyanti Butar Butar \\ Fakultas Ekonomi dan Bisnis Universitas Sebelas Maret \\ gabgabryelabb@gmail.com \\ Halim Dedy Perdana \\ Fakultas Ekonomi dan Bisnis Universitas Sebelas Maret \\ perdana.hlm@gmail.com
}

\begin{abstract}
The purpose of this research is to describe the implementation of government internal auditor's professional skepticism in fraud detection. The implementation of professional skepticism will be based on the characters stated by Hurtt et al., (2010): questioning mind, suspension on judgment, search for knowledge, interpesonal understanding, self-confidence, and self-determination. This is a qualitative research referring to theoretical proposition. The data was collected by interviewing forensic auditors at each of functional position. The interviewees were determined by using purposive sampling method. They are forensic auditors claimed due to audit report. The result showed that forensic auditors in Representative Office of BPKP in Central Java implement professional skepticism in fraud detection. Auditor hold responsible of audit report proved by five of six claims received are rejected and one claim is still in litigation.
\end{abstract}

Keywords: professional skepticism, the government internal auditor, fraud detection.

\begin{abstract}
ABSTRAK
Penelitian ini bertujuan untuk mendeskripsikan penerapan skeptisisme profesional auditor internal pemerintah di Perwakilan BPKP Provinsi Jawa Tengah dalam mendeteksi kecurangan. Penerapan skeptisisme profesional akan dipahami berdasarkan karakteristik sikap yang membentuknya sebagaimana dinyatakan oleh Hurtt et al., (2010) antara lain questioning mind, suspension on judgment, search for knowledge, interpesonal understanding, self-confidence, dan self-determination. Penelitian menggunakan pendekatan kualitatif dan mengacu pada proposisi teori. Pengumpulan data dilakukan dengan teknik wawancara kepada auditor investigasi dari setiap jabatan fungsional tim audit. Responden wawancara ditentukan dengan teknik purposive sampling yaitu auditor investigasi yang pernah menerima gugatan terkait hasil audit. Hasil penelitian menunjukkan bahwa auditor investigasi Perwakilan BPKP Provinsi Jawa Tengah menerapkan skeptisisme profesional dalam
\end{abstract}


mendeteksi kecurangan. Auditor mampu mempertanggungjawabkan kebenaran laporan hasil auditnya dengan ditolaknya lima gugatan dari enam gugatan yang diterima Perwakilan BPKP Provinsi Jawa Tengah. Sedangkan satu gugatan masih dalam proses pengadilan.

Kata Kunci: skeptisisme profesional, auditor internal pemerintah, deteksi kecurangan.

\section{PENDAHULUAN}

Fenomena kecurangan (fraud) yang digambarkan sebagai "white collar crime" kerap terjadi dalam pengelolaan keuangan publik. Tingkat kecurangan suatu negara ditunjukkan oleh tingkat korupsi negara tersebut (Shleifer dan Vishny 1993). Tranparency International (TI) merilis Corruption Perceptions Index (CPI) dimana Indonesia menempati peringkat ke 88 dari 168 negara dengan skor 36 pada tahun 2015. Ini menunjukkan tingginya angka korupsi di sektor publik Indonesia.

Sejak bergulirnya reformasi, tuntutan akan transparansi dan akuntabilitas terhadap pengelolaan keuangan publik semakin kuat. Hal ini ditandai dengan diimplementasikannya konsep New Public Management yang diasosiasikan dengan New Public Financial Management (NPFM). Banyak negara telah mengimplementasikan reformasi NPFM, seperti Australia, New Zealand, Spanyol, Swedia, Inggris, Amerika Serikat, Kanada, Irlandia, Italia, Belanda, and negaranegara di Eropa, seperti Bulgaria, Lithuania, dan Romania (Guthrie et al., 2005). Konsep ini mengacu pada good governance (tata kelola pemerintahan) yang baik. Guthrie et al. (2005) mengidentifikasi lima kategori yang termasuk dalam lingkup NPFM, salah satunya perubahan audit internal dan eksternal pada sektor publik. Di Indonesia, fungsi pengawasan (audit internal) menjadi fokus agenda perubahan sehingga peran auditor internal pun turut menjadi fokus perhatian.

Seorang auditor harus dapat menghasilkan kualitas audit yang baik dan dapat diandalkan. Untuk dapat menghasilkan kualitas audit yang baik, auditor bertanggung jawab merencanakan dan melaksanakan audit demi mendapatkan kepastian bahwa laporan keuangan tidak mengandung kesalahan material yang disebabkan oleh kecurangan maupun kekeliruan (Auditing Standard Boards 2011). Namun berdasarkan hasil penilaian tingkat kapabilitas oleh Badan Pengawasan Keuangan dan Pembangunan (BPKP) per 31 Desember 2014, sebesar 85,23 persen Auditor Internal Pemerintah yang tersebar di Kementerian, Lembaga, dan Instansi Pemerintah Daerah, berada pada level 1. Hal ini menunjukkan Auditor Internal Pemerintah memiliki kapabilitas yang rendah dan belum dapat mendeteksi kecurangan (korupsi). Rendahnya kapabilitas auditor internal pemerintah dalam mendeteksi kecurangan dapat disebabkan oleh kurangnya penerapan sikap skeptisisme profesional. Peterson dan Buckhoff (2004); Martin dan Phillips (2006) menyatakan skeptisisme profesional merupakan sikap yang penting dimiliki oleh 
auditor dalam mendeteksi kecurangan. Selain itu, Quadackers et al. (2009) menyatakan bahwa auditor internal dengan tingkat skeptisisme yang tinggi dapat mendeteksi kecurangan secara dini mulai dari tahapan perencanaan hingga pelaksanaan audit. Dalam menjalankan tugasnya, auditor internal pemerintah perlu untuk mempertimbangkan kemungkinan adanya kecurangan yang terjadi pada setiap tahapan kegiatan operasional di suatu organisasi. Oleh karena itu, sikap skeptisisme profesional auditor perlu menjadi perhatian dalam melakukan pendeteksian kecurangan saat melaksanakan audit.

Skeptisisme berasal dari bahasa Yunani "skeptesthai" yang berarti menguji, menyelidiki, mempertimbangkan. Kaum skeptis selalu meragukan setiap klaim pengetahuan, karena memiliki sikap tidak puas dan masih mencari kebenaran. Skeptisisme diartikan sebagai aliran atau paham yang memandang sesuatu selalu tidak pasti, meragukan, dan mencurigakan. Skeptisisme profesional merupakan sikap mutlak yang harus dimiliki auditor (Tuanakotta 2013). Dalam situasi apapun setiap auditor dituntut untuk mempunyai sikap skeptisisme profesional seperti yang tercantum dalam SAS No. 99 Tahun 2002. Skeptisisme profesional mencakup pikiran yang selalu mempertanyakan dan melakukan evaluasi secara kritis terhadap bukti audit. Karena bukti audit dikumpulkan dan dinilai selama proses audit, maka skeptisisme profesional harus digunakan selama proses tersebut. Auditor tidak boleh menganggap bahwa manajemen entitas yang diperiksa tidak jujur, tetapi juga tidak boleh menganggap bahwa kejujuran manajemen tersebut tidak diragukan lagi.

Auditor internal pemerintah terdiri dari BPKP, Inspektorat Jenderal atau nama lain yang secara fungsional melaksanakan pengawasn intern, Inspektorat Provinsi, dan Inspektorat Kabupaten/Kota (PP No 60 tahun 2008). Auditor internal pemerintah melakukan pengawasan melalui audit, reviu, evaluasi, pemantauan, dan kegiatan pengawasan lainnya. BPKP memiliki kapasitas untuk melaksanakan kegiatan penugasan di bidang pemberantasan korupsi yang dilakukan dengan tiga jenis pendekatan, antara lain preemtif (pendidikan), preventif (pencegahan), dan pemberian sanksi (represif). Di antara ketiga jenis pendekatan tersebut, penugasan yang bersifat represif (seperti audit investigasi, audit perhitungan kerugian keuangan negara, dan pemberian keterangan ahli) lebih mendominasi dalam target penetapan dan capaian kinerja.

Dalam menjalankan fungsinya yang bersifat represif, BPKP terkadang menerima gugatan, salah satunya terkait keabsahan hasil audit. Seperti gugatan yang dilayangkan kepada Perwakilan BPKP Jawa Tengah oleh Kepala Dinas A terkait hasil audit kegiatan X di kota O. Menurut Kepala Dinas A, BPKP melaksanakan audit kerugian tersebut tidak sesuai standar operasional prosedur, sebab auditor tidak didampingi ahli independen dan hanya didasarkan pada keterangan pekerja lapangan. Hal serupa terjadi pada tahun 2013, mantan Kepala Badan B menggugat Perwakilan BPKP Provinsi Jawa Tengah dengan materi gugatan audit BPKP dinilai tidak benar 
dalam penanganan Kasus Tindak Pidana Korupsi (TPK) pada kegiatan Y Kabupaten P. Kondisi tersebut mendorong peneliti untuk memperoleh pemahaman terkait praktek pendeteksian kecurangan oleh auditor Perwakilan BPKP Provinsi Jawa Tengah yang dilihat dari skeptisisme profesional sesuai karakteristik sifat pembentuknya menurut Hurtt et al. (2010) antara lain questioning mind, suspension of judgment, search for knowledge, interpersonal understanding, self-confidence, dan self-determination.

Penelitian ini terinspirasi dari beberapa penelitian terdahulu. Fullerton dan Durtschi (2005) yang melakukan pengujian pengaruh skeptisisme profesional terhadap kemampuan auditor internal dalam mendeteksi kecurangan. Dalam penelitiannya, karakteristik skeptisisme menurut Hurtt et al. (2010) digunakan untuk mengklasifikasikan auditor internal apakah skeptis atau kurang skeptis. Hasil penelitian tersebut menunjukkan bahwa auditor internal dengan tingkat skeptisisme lebih tinggi memiliki kemampuan yang lebih besar untuk memperoleh informasi atas kecurangan. Sejalan penelitian Beasley et al. (2001) yang didasarkan pada AAERs (Accounting and Auditing Releases), selama 11 periode (Januari 1987 - Desember 1997) menyatakan bahwa salah satu penyebab kegagalan auditor dalam mendeteksi laporan keuangan adalah rendahnya tingkat skeptisisme profesional audit. Berdasarkan penelitian ini, dari 45 kasus kecurangan dalam laporan keuangan, 24 kasus (60 persen) di antaranya terjadi karena auditor tidak menerapkan tingkat skeptisisme profesional yang memadai. Hal ini membuktikan bahwa skeptisisme profesional harus dimiliki dan diterapkan oleh auditor. Namun berbeda dengan Castro (2013) menyatakan bahwa tingkat skeptisisme yang tinggi tidak dapat mempengaruhi pertimbangan profesional seorang auditor internal dalam mendeteksi kecurangan.

Penelitian skeptisisme dalam konteks Indonesia sudah banyak dilakukan oleh Anggriawan (2014) dan Pramudyastuti (2014). Hasil penelitian mereka menyatakan skeptisisme profesional berpengaruh terhadap kemampuan auditor dalam mendeteksi kecurangan. Hasil tersebut berbeda dengan hasil penelitian Gusti dan Ali (2008) yang menguji pengaruh skeptisisme auditor yang dikontrol oleh situasi audit, etika, pengalaman, dan keahlian audit terhadap pendeteksian kecurangan oleh akuntan publik. Hasil penelitian tersebut menunjukkan bahwa skeptisisme profesional tidak berpengaruh terhadap pendeteksian kecurangan oleh akuntan publik. Kondisi hasil penelitian terdahulu menunjukkan senjang riset tentang skeptisisme profesional dalam mendeteksi kecurangan. Adanya perbedaan hasil penelitian tentang skeptisisme professional mendorong dilakukannya penelitian ini, namun dilaksanakan dalam konteks auditor internal pemerintah.

\section{Skeptisisme Profesional Auditor Internal Pemerintah}

Skeptisisme merupakan sifat individual, dapat berbentuk bawaan (trait), yakni aspek yang stabil dan bertahan lama dalam diri seorang individu dan juga 
situasional (state), yakni kondisi sementara yang dipengaruhi oleh situasi (Hurtt, Eining, \& Plumlee 2010). Dalam kerangka skeptisisme profesionalnya, skeptisisme bawaan dan skeptisisme situational akan membentuk pola pikir skeptis dan pola pikir skeptis akan membentuk tindakan skeptis.

Skeptisisme profesional yaitu sikap yang meliputi pikiran yang selalu bertanya tanya (questioning mind), waspada (alert) terhadap kondisi dan keadaan yang mengindikasikan adanya kemungkinan salah saji material yang disebabkan oleh kesalahan atau kesengajaan (fraud), dan penilaian (assessment) bukti-bukti audit secara kritis. Internasional Federation of Accountant (IFAC) mendefinisikan skeptisme profesional dalam konteks evidence assessment atau penilaian atas bukti menyatakan bahwa:

"skepticism means the auditor makes a critical assessment, with a questioning mind, of the validity of audit evidence obtained and is allert to audit evidence that contradicts or brings into the reliability of documents and responses to inquiries and other information obtained from management and those charged with governance" (ISA 200.16)

Menurut Tuanakotta (2012), unsur-unsur skeptisisme profesional dalam definisi IFAC: 1) a critical assessment - ada penilaian yang kritis, tidak menerima begitu saja; 2) with a question mind - dengan cara berfikir yang terus menerus bertanya dan mempertanyakan; 3) of the validity of audit evidence obtained keabsahan dari bukti yang diperoleh; 4) allert to audit evidence that contradicts waspada terhadap bukti yang kontradiktif; 5) brings into question the reliability of documents and responses to inquiries and other information - mempertanyakan keandalan dokumen dan jawaban atas pertanyaan serta informasi lainnya; dan 6) obtained from management and those charged with governance - yang diperoleh dari manajemen dan mereka yang berwenang dalam pengelolaan (perusahaan).

Hurtt et al. (2010) mengembangkan enam karakteristik skeptisisme profesional yang pertama terdiri dari tiga karakteristik yang berhubungan dengan pemeriksaan dan pengujian bukti (examination of evidence) yaitu questioning mind, suspension of judgment, dan search for knowledge. Karakteristik keempat terkait dengan pertimbangan aspek manusia dan pemahaman penyedia informasi (understanding evidence providers) ketika mengevaluasi bukti audit yaitu interpersonal understanding. Dua karakteristik terakhir yaitu self-confidence dan self-determination berkenaan dengan keberanian profesional auditor.

\section{Questioning Mind}

Karakteristik skeptisisme profesional yang pertama ialah pikiran yang selalu mempertanyakan sesuatu. Seseorang yang bersikap skeptis akan mempertanyakan suatu alasan, penyesuaian, dan pembuktian, akan sesuatu yang dihadapinya atau diperolehnya. Fogelin (1994) menyebut skeptis filosofis (philosopical) sebagai seseorang yang meragukan sesuatu atau membuat sesuatu menjadi pertanyaan. 
Standar Profesional Akuntan Publik (PSA No. 4 Tahun 2011) menyatakan skeptisisme profesional yaitu sikap auditor yang berpikir kritis terhadap bukti audit dengan selalu mempertanyakan dan melakukan evaluasi terhadap bukti audit tersebut. Karakter ini dibentuk dari beberapa indikator, yaitu menolak suatu pernyataan atau statement tanpa pembuktian yang jelas dan mengajukan banyak pertanyaan untuk pembuktian akan suatu hal.

\section{Suspension on Judgment}

Karakteristik skeptisisme profesional yang kedua ialah penangguhan dalam penilaian. Dimensi skeptisisme profesional ini mengarah ke perilaku yang menunda membuat kesimpulan audit sampai bukti yang cukup terkumpul (Hurtt, Eining, \& Plumlee 2010). Karakter ini dibentuk dari beberapa indikator yaitu membutuhkan informasi yang lebih banyak, membutuhkan waktu dalam membuat suatu keputusan, dan tidak akan membuat keputusan jika semua informasi belum terungkap.

\section{Search for Knowledge}

Karakteristik skeptisisme profesional yang ketiga ialah pencarian pengetahuan. Skeptis didasari rasa ingin tahu (curiosity) yang tinggi. Rasa ingin tahu tersebut ditujukan untuk menambah pengetahuan yang dapat digunakan dalam melakukan audit. Motivasi individu berperan besar terhadap proses pencarian pengetahuan, dari memulai pencarian pengetahuan sampai mengakhiri proses ketika pembuat keputusan merasa dia telah memperoleh pengetahuan yang cukup (Bailey et al. 2007). Karakter ini dibentuk dari beberapa indikator yaitu lebih banyak mencari dan berusaha menemukan informasi informasi baru yang up to date, menyenangkan bila menemukan hal hal yang baru, dan tidak akan membuat keputusan jika semua informasi belum terungkap.

\section{Interpesonal Understanding}

Karakteristik skeptisisme profesional yang keempat ialah pemahaman antar pribadi. Seseorang yang bersikap skeptis berusaha memahami tujuan, motivasi, dan integritas dari penyedia informasi. Hal ini dilakukan untuk mengidentifikasi apakah informasi yang diberikan valid atau tidak. Karakter ini dibentuk dari beberapa indikator yaitu berusaha untuk memahami perilaku orang lain dan alasan mengapa seseorang berperilaku.

\section{Self Confidence}

Karakteristik skeptisisme profesional yang kelima ialah percaya diri. Hurtt et al. (2010) menunjukkan bahwa skeptisisme profesional melibatkan percaya diri (berupa pengarahan diri dan kemandirian moral). Seorang auditor yang bersikap skeptis percaya akan kemampuan dirinya sendiri untuk secara profesional dapat merespon dan mengolah semua bukti yang sudah dikumpulkan. Dia cenderung memilih untuk mencari informasi sendiri dan tidak menggantungkan diri terhadap 
pernyataan dari informasi yang diperoleh. Karakter ini dibentuk dari beberapa indikator, yaitu percaya akan kapasitas dan kapabilitas diri sendiri.

\section{Self Determination}

Karakteristik skeptisisme profesional yang keenam ialah determinasi diri. Seorang auditor yang bersikap skeptis menyimpulkan sesuatu secara objektif atas bukti yang sudah dikumpulkan. Ia memutuskan untuk dirinya sendiri tingkat bukti yang diperlukan untuk menerima hipotesis tertentu (Hurtt, Eining, \& Plumlee 2010). Karakter ini dibentuk dari beberapa indikator yaitu tidak langsung menerima atau membenarkan pernyataan dari orang lain, mempertimbangkan penjelasan dan tanggapan orang lain, menekankan pada suatu hal yang bersifat tidak konsisten, dan tidak mudah dipengaruhi oleh orang lain akan suatu hal.

\section{METODA PENELITIAN}

Pendekatan yang digunakan dalam penelitian ini adalah pendekatan kualitatif, dengan studi kasus. Narasumber penelitian ini adalah auditor bidang investigasi Perwakilan BPKP Jawa Tengah, yang pernah menerima gugatan terkait hasil audit. Auditor sampel diambil dari tiap jabatan dalam tim audit antara lain pengendali mutu, pengendali teknis, ketua tim, dan anggota tim.

Penelitian ini menggunakan teknik wawancara yang mendalam dalam pengumpulan data karena bertujuan untuk mengumpulkan informasi yang kompleks, yang sebagian besar berisi pendapat, sikap, dan pengalaman pribadi. Analisis data menggunakan model interaktif yang meliputi dengan tahapan pengumpulan data, reduksi data, paparan data, verifikasi dan penarikan kesimpulan. Pengujian keabsahan hasil penelitian dengan cara menemukan siklus kesamaan data, kecukupan referensi, triangulasi, serta diskusi dengan dosen pembimbing dan rekan sejawat.

\section{ANALISIS DAN PEMBAHASAN}

\section{Pemahaman Auditor terhadap Skeptisisme Profesional}

Skeptisisme profesional berperan penting dalam menentukan kualitas audit. Pola pikir skeptis cenderung mengarah ke penilaian audit yang lebih konservatif yang pada gilirannya dapat meningkatkan kemungkinan auditor mendeteksi kecurangan (Popova 2013; Cohen et al., 2014). Hal yang sama juga dinyatakan oleh regulator audit (PCAOB 2011 dan IAASB 2012) bahwa tingginya tingkat skeptisisme profesional dapat mengurangi risiko kegagalan audit dan mengurangi resiko memperoleh reputasi negatif dari sanksi disiplin dan litigasi.

Pemahaman mengenai konsep skeptisisme profesional menyebabkan variasi dalam praktek skeptisisme sendiri. Oleh karenanya peneliti menggali pemahaman 
setiap responden dalam pendahuluan wawancara. Paparan para responden terkait skeptisisme profesional diuraikan sebagai berikut.

Responden PM menyatakan

"Skeptisisme profesional merupakan sikap yang hanya dapat menilai suatu informasi berdasarkan bukti. Informasi apapun dan dari pihak manapun harus didukung oleh bukti lain karena informasi sangat dipengaruhi subjektivitas penyedia informasi".

Dengan kata lain skeptisisme profesional berarti tidak membuat penilaian kecuali berdasarkan bukti tanpa dipengaruhi sumber bukti. Pemahaman tersebut tercermin pada salah satu aspek skeptisisme profesional menurut Hurtt et al. (2010) yaitu penundaan penilaian audit sampai bukti yang cukup telah dikumpulkan.

Responden PT mengungkapkan

"Skeptisisme profesional adalah sikap yang meragukan, mencurigai, dan tidak mempercayai kebenaran suatu hal. Konsekuensi dari sikap ini adalah selalu mempertanyakan segala sesuatu, mencari pembuktian akan hal tersebut, dan menilai secara kritis bukti tersebut sebelum mempercayainya."

Responden PT memandang skeptisisme profesional dari perpektif keraguan preasumtif. Pemahaman tersebut sesuai dengan pernyataan Shaub dan Lawrence (1996) yang menjadikan rasa tidak percaya sebagai dasar dari perilaku skeptisisme profesional sehingga auditor dituntut untuk memiliki pemikiran yang curiga dan melakukan pengujian tambahan saat melakukan audit sehingga didapatkan keyakinan yang memadai terhadap bukti yang diperoleh.

Responden KT mengutarakan

"Skeptisisme profesional berarti pesimis dan kurang percaya secara profesional.

Hal ini berbeda dengan mencari cari kesalahan. Setiap informasi yang diterima harus diuji lagi kebenarannya."

Demikian halnya Hurtt et al. (2008) juga memandang skeptisisme profesional sebagai suatu sikap yang mencerminkan rasa ketidakpercayaan.

Responden AT menyatakan,

"Skeptisisme profesional sebagai sikap kritis terhadap suatu bukti dengan menguji keakuratannya sebelum meyakini dan menggunakan bukti tersebut."

Hal ini berkaitan dengan sikap auditor dalam membentuk keyakinan terhadap bukti. Pemahaman tersebut tertera dalam unsur-unsur profesional skeptisisme dalam definisi IFAC mempertanyakan validitas bukti, keandalan dokumen, dan jawaban atas pertanyaan serta informasi lainnya. 


\section{Penerapan Skeptisisme Profesional}

\section{Questioning Mind}

Pikiran yang selalu mempertanyakan sesuatu mengacu pada sikap individu yang berkaitan dengan rasa ingin tahu dan minat (Hurtt, Eining, \& Plumlee 2010). Dalam literatur filsafat, penyelidikan, pembuktian asersi, bertanya secara aktif, dan keingintahuan termasuk dalam karakter ini (Stough 1969; Bunge 1991; Kurtz 1992; Fogelin 1994). Penerapan karakter questioning mind diuraikan sebagai berikut.

Responden PM menjelaskan,

“Dalam penugasan, saya selalu mempertanyakan sesuatu yang saya peroleh dan hadapi. Tujuannya untuk mencari akar permasalahan (root cause analysis) sampai saya menemukan fakta yang sebenarnya."

Root Cause Analysis (RCA) merupakan alat yang digunakan dalam inisiatif problem solving. Salah satu metode dalam RCA ialah why why analysis atau sering disebut 5whys analysis. Responden PM menanyakan "mengapa" berulang kali sampai menemukan jawaban yang paling dasar. Penerapan karakter ini dinyatakan juga oleh Kurtz (1992) bahwa auditor yang memiliki pikiran yang mempertanyakan akan terus mengajukan pertanyaan untuk tujuan klarifikasi dan pengertian lebih lanjut, alasan yang diperlukan, pembenaran atau pembuktian.

Responden PT menuturkan,

"Saya berpikir kritis dengan menguji setiap informasi dan bukti baik yang diperoleh sendiri maupun diperoleh dari pihak lain (penyidik) untuk memperoleh keyakinan akan kebenarannya sehingga dapat dijadikan dasar pengambilan keputusan."

Responden PT mempertanyakan dan mengevaluasi apakah bukti telah memenuhi kriteria cukup, kompeten, dan relevan. Bukti audit disebut cukup jika jumlah bukti yang dikumpulkan sudah dapat dijadikan sebagai dasar untuk penarikan suatu kesimpulan audit. Bukti audit dikatakan kompeten jika bukti tersebut sah dan dapat diandalkan untuk menjamin kesesuaian dengan faktanya. Bukti yang sah adalah bukti yang memenuhi persyaratan hukum dan peraturan perundang-undangan. Bukti yang dapat diandalkan berkaitan dengan sumber dan cara perolehan bukti itu sendiri. Bukti audit disebut relevan jika bukti tersebut secara logis mendukung atau menguatkan pendapat atau argumen yang berhubungan dengan tujuan dan kesimpulan audit. Penerapan karakter ini selaras dengan Kurtz (1992) yang mempresentasikan skeptis dengan berpikir secara terbuka dan mengevaluasi bukti dengan kritis.

Responden KT mengungkapkan,

"Saya tidak menerima suatu pernyataan dan informasi begitu saja (tanpa pembuktian yang jelas). Berita Acara Pemeriksaan (BAP) yang diperoleh dari penyidik pun harus dievaluasi lagi dengan mengupayakan klarifikasi maupun uji silang dengan keterangan saksi lain atau bukti lain agar tidak menyesatkan. 
Semakin banyak pihak mengkonfirmasi suatu informasi, maka semakin besar kemungkinan informasi tersebut benar."

Responden PT mempertanyakan informasi dalam BAP dan mengujinya lagi dengan melakukan upaya klarifikasi, konfirmasi, dan pencarian alternatif bukti lain. Alat bukti untuk mengungkapkan kecurangan dalam audit investigasi harus sah menurut Kitab Undang-Undang Hukum Acara Pidana (KUHAP) pasal 184 antara lain keterangan saksi, keterangan ahli, surat, petunjuk, dan keterangan terdakwa. Penerapan karakter ini sesuai dengan gambaran filsuf terhadap skeptis yaitu tidak bersedia untuk menerima pernyataan dan klaim dengan mudah (Kurtz 1992).

Responden AT mengatakan,

"Saya mengajukan pertanyaan sejumlah yang cukup untuk pembuktian akan suatu hal. Setiap informasi dan bukti harus dikaji lebih lanjut dan dicari alternatif alat bukti lain yang sah untuk mendukung kevalidan bukti tersebut."

Responden AT mempertanyakan $5 \mathrm{~W}+1 \mathrm{H}$ untuk membuktikan dugaan terjadinya kecurangan. Informasi yang diperoleh meliputi jawaban atas pertanyaan "what" (jenis penyimpangan apa yang terjadi), "who" (siapa pihak-pihak yang terkait), "where" (di mana tempat terjadinya penyimpangan), "when" (kapan waktu terjadinya penyimpangan), "why" (penyebab terjadinya penyimpangan), dan "how" (bagaimana modus penyimpangan). Penerapan karakter ini selaras dengan Louwers (2005) yang menyatakan sikap skeptis akan mendorong auditor untuk selalu mengajukan pertanyaan mengenai petunjuk apapun yang mungkin mengindikasikan adanya fraud.

\section{Suspension on Judgment}

Penangguhan penilaian mengarah pada penahanan penilaian hingga tercapai tingkat bukti layak untuk dijadikan dasar keputusan (Hurtt, Eining, \& Plumlee 2010). Melalui studi empiris, Quadackers et al. (2009) menyatakan karakter skeptis berpengaruh secara positif terhadap penilaian dan keputusan auditor. Penerapan karakter suspension on judgment diuraikan sebagai berikut.

Responden PM menyatakan,

"Saya mengambil keputusan dalam setiap keadaan dan hanya dapat mengambil simpulan audit jika terdapat bukti yang cukup. Keputusan audit tidak dapat ditunda karena merupakan langkah audit berikutnya yang akan dilakukan namun auditor harus menunda pengambilan simpulan sampai bukti cukup. Jika auditor belum dapat membuktikan terjadinya suatu dugaan, maka putuskan mencari bukti tambahan. Namun jika tidak berhasil maka putuskan untuk menghentikan audit dan simpulan audit tidak dapat diambil."

Dalam hal responden PM menilai bahwa bukti belum cukup, maka responden memutuskan untuk mencari bukti tambahan. Jika akhirnya tidak berhasil maka responden memutuskan untuk menghentikan audit dan simpulan terjadinya dugaan kecurangan tidak dapat diambil. Penerapan karakter ini sesuai dengan pernyataan 
Hurtt et al. (2010) yakni skeptisisme profesional merupakan konstruk multi-dimensi yang bercirikan kecenderungan individu untuk menunda penyimpulan sampai bukti yang tersedia cukup mendukung suatu alternatif / penjelasan atas orang lain.

Responden PT mengungkapkan,

"Saya tidak tergesa gesa dalam mengambil simpulan sampai saya yakin akan kecukupan bukti yang diperoleh. Pengambilan simpulan audit investigasi tidak dapat dibatasi waktu."

Kecukupan bukti dalam memberikan keyakinan yang memadai merupakan salah satu dasar untuk semua pertimbangan dan simpulan hasil penugasan bidang investigasi. Unit Kerja BPKP dilarang menerbitkan laporan apabila masih terdapat prosedur yang masih belum dilaksanakan dan ketidakcukupan bukti-bukti yang diperoleh sehingga laporan dapat menyesatkan.

\section{Responden KT mengutarakan,}

"Saya melakukan penangguhan simpulan audit investigasi jika bukti kurang. Namun jika bukti tidak dapat diperoleh lagi maka saya akan membuat simpulan tidak terbukti ada penyimpangan dan berikan pernyataan tambahan "jika terdapat bukti baru dikemudian hari maka akan dilakukan peninjauan kembali”.,

Penilaian terhadap kurangnya bukti oleh responden KT sesuai dengan yang dinyatakan oleh (AU 230, 9) bahwa auditor sebaiknya tidak puas dengan bukti yang kurang meyakinkan. Kemudian responden KT memutuskan untuk mencari bukti tambahan. Penilaian keadaan bahwa bukti tidak ditemukan dilakukan dengan matang. Hal ini sesuai dengan Mautz and Sharaf (1961) yang menyatakan auditor hanya dapat melakukan penilaian setelah mengevaluasi bukti yang tersedia dengan layak.

Responden AT menyatakan,

"Saya cenderung menunda membuat simpulan sampai bukti audit cukup dan jika waktu kurang dalam mengumpulkan bukti maka surat tugas diperpanjang."

Sikap penundaan ini dijelaskan Bunge (1991) dalam ilmu filsafat dimana orang yang skeptis perlu melihat bukti sebelum mempercayai sesuatu sehingga memperlambat proses pembentukan penilaian. Perpanjangan waktu pelaksanaan audit investigasi diperbolehkan namun harus didasarkan pada alasan yang dapat diterima dan diberikan sesuai dengan kebutuhannya. Kondisi tersebut dituangkan dalam laporan kemajuan penugasan (progress report). Penugasan yang sudah melampaui batas waktu diidentifikasi hambatan dan kendala yang dihadapi, dan dilaporkan oleh pimpinan unit kerja (kepala perwakilan BPKP) kepada Deputi Kepala BPKP Bidang Investigasi.

\section{Search for Knowledge}

Pencarian pengetahuan mengarah pada ketertarikan terhadap pengetahuan secara umum dan tidak hanya untuk memverifikasi kesimpulan tertentu atau 
mendapatkan informasi tertentu. Aspek ini dijelaskan dalam filsafat, orang yang berkarakter skeptis mencari pengetahuan untuk pengetahuan itu sendiri Johnson (1978) dan memiliki dorongan dan keinginan untuk menyelidiki Bunge (1991). Penerapan karakter search for knowledge diuraikan sebagai berikut.

Responden PM menyatakan,

"Saya termotivasi untuk mencari pengetahuan karena ilmu investigasi selalu berkembang dari waktu ke waktu. Pengetahuan mengenai teori audit, pedoman audit organisasi, serta peraturan terbaru yang berhubungan dengan penugasan audit dapat diperoleh melalui perpustakaan dan website. Kasus demi kasus baik dari media informasi umum maupun buletin asosiasi juga dipelajari karena kenyataannya tidak ada dua kasus yang identik. Saya juga mengikuti pendidikan dan pelatihan (diklat) keinvestigasian baik di dalam maupun diluar negeri.",

Pengetahuan fraud dapat diperoleh melalui pengalaman langsung seperti pendidikan terkait fraud dan pelatihan. Melalui penelitiannya, Fullerton dan Durtschi (2005) menyatakan bahwa pelatihan fraud-awareness mempengaruhi skeptisisme auditor internal dalam mengumpulkan informasi. Penerapan karakter ini meningkatkan kemampuan responden PM dalam mendeteksi kecurangan.

Responden PT menyatakan,

"Saya menggali pengetahuan dengan mengikuti seminar terkait fraud dan mengikuti gelar perkara (ekspose awal) yang dilakukan oleh penyidik kejaksaan/polri untuk mengetahui modus kecurangan dari suatu perkara. Ini menjadi tantangan tersendiri baginya untuk menemukan kecurangan tersebut."

Ekspose awal merupakan penelaahan kasus yang dilakukan dalam bentuk focus group discussion (FGD). Pihak yang berkepentingan terhadap kasus seperti aparat penegak hukum atau pihak lain memaparkan kronologis penyimpangan dan dilanjutkan dengan diskusi mengenai perbuatan melawan hukum, aturan yang dilanggar atau telah terjadi peyalahgunaan wewenang yang disertai dengan niat jahat (mens rea) dari pelakunya. Melalui ekspose awal ini, responden PT memperoleh pengetahuan terkait kecurangan baik dari pihak yang berkepentingan maupun rekan auditor lainnya.

Responden KT menyatakan

"Saya selalu mencari pengetahuan mengenai teknik audit terbaru salah satunya audit berbantuan komputer. Hal ini merupakan suatu tuntutan profesional dalam pekerjaan. Motivasi dari dalam diri saya ialah keinginan untuk mengungkapkan fakta sehingga tidak ada pihak yang dizolimi."

Pengelolaan keuangan negara telah mengadopsi perkembangan teknologi. Responden KT merasa perlu menguasai teknologi dan sistem informasi dalam rangka membantu mengungkapkan kecurangan dan memudahkan penyelesaian proses audit secara efektif dan efisien. Askary et al. (2012) mengungkapkan kemajuan dalam 
mendeteksi fraud IT secara positif mengurangi risiko audit dan secara signifikan telah meningkatkan kualitas audit.

Responden AT menyatakan,

"Saya mencari pengetahuan melalui diklat dan Program Pengembangan Mutu $(P P M)$. Informasi up to date juga dapat diperoleh melalui media cetak dan elektronik."

Penerapan karakter ini diungkapkan juga oleh Saksena (2008) bahwa pelatihan merupakan elemen penting yang akan membantu auditor dalam pencegahan dan pendeteksian fraud. PPM sebagai produk kebijakan BPKP merupakan salah satu upaya untuk meningkatkan kompetensi pegawai BPKP melalui paparan materi oleh auditor yang mengikuti kegiatan diklat bersifat substansif. PPM menjadi media transfer knowledge kepada rekan auditor lainnya.

\section{Interpesonal understanding}

Pemahaman Interpersonal mengacu pada pemahaman alasan atau motivasi dari seorang individu yang mendorong perilaku seseorang (Hallie 1985). Dari perspektif audit, karakter ini mengarah pada sejauh mana auditor mengerti motivasi dan integritas individu yang menyajikan bukti audit. Penerapan karakter interpesonal understanding diuraikan sebagai berikut.

Responden PM menuturkan,

"Pemahaman terhadap diri penyedia informasi sangat diperlukan karena keterangan yang diperoleh dapat bersifat subjektif. Auditor investigasi mengenali pribadi penyedia informasi, hubungan, dan kepentingan orang tersebut dengan kasus sehingga auditor dapat memahami persepsi dan alasan orang tersebut berperilaku. Begitu juga saat wawancara, auditor investigasi harus menilai kejujuran seseorang dan konsistensi jawaban atas pertanyaan yang diajukan untuk menentukan apakah informasi dari orang tersebut dapat digunakan atau tidak."

Kejujuran klien diidentifikasi secara eksplisit dalam yaitu berbagai dorongan dan kesempatan yang dimiliki klien untuk menyajikan bukti yang menyesatkan atau melakukan penipuan. Penerapan karakter ini serupa dengan direkomendasikannya pengenalan terhadap kemungkinan komunikasi yang kurang jujur AU316.87.A2-A3.

Responden PT menyatakan,

"Saya berusaha memahami tujuan, motivasi, dan integritas dari penyedia informasi untuk mengambil langkah berikutnya terkait informasi yang diberikan."

Dalam literatur filsafat diuraikan tanpa pemahaman terhadap orang, sulit untuk mengenali potensi bias yang terdapat dalam informasi yang diberikan oleh pihak lain, dan sulit untuk mendeteksi ketika orang mungkin sengaja memberikan informasi yang menyesatkan. Asumsi atau motivasi individu yang diidentifikasi dan dipahami merupakan dasar untuk meragukan atau mengoreksi asumsi yang salah (Hallie 1985, Hookway 1990, Kurtz 1992, McGinn 1989). 


\begin{abstract}
Responden KT mengungkapkan,
"Pemahaman personal diperlukan auditor agar dapat menyusun strategi dan menyesuaikan teknik audit dengan cara memposisikan dirinya sebagai tersangka maupun pihak penyedia informasi. Saya juga berusaha mengerti pemahaman, persepsi, dan perilaku orang lain. Hal ini membantu auditor agar dapat menggali informasi lebih banyak."
\end{abstract}

Penerapan karakter ini sesuai dengan representasi Hurtt et al. (2003) bahwa orang yang skeptis akan mempelajari dan memahami individu lain yang memiliki pandangan dan persepsi yang berbeda mengenai suatu hal. Dengan memahami persepsi orang lain, orang yang skeptis akan melakukan penilaian dan menyesuaikan teknik prosedur yang tepat untuk memperoleh bukti dan mengungkapkan kecurangan

Responden AT menjelaskan,

"Saya melakukan pendekatan sebelum wawancara atau klarifikasi untuk memahami cara berpikir, keterkaitan dengan kasus dan latar belakang penyedia informasi."

Pendekatan terhadap responden wawancara ataupun informan klarifikasi termasuk dalam interaksi sosial auditor. Dalam psikologi, penelitian terkait kompetensi sosial yang sering dideskripsikan dengan istilah keterampilan sosial dan interaksi sosial merupakan gambaran terbaik aspek interpersonal skeptisisme professional (Helmreich et al., 1974).

\title{
Self Confidence
}

Karakter percaya diri mengacu kepada rasa harga diri dan percaya pada kemampuan diri sendiri (Hurtt et al., 2010). Auditor yang memiliki sifat ini lebih yakin dalam menjalankan tugas audit dengan efektif dan membuat keputusan dan kesimpulan audit sendiri (Boush et al., 1994). Penerapan karakter self confindence diuraikan sebagai berikut.

Responden PM mengemukakan,

"Saya percaya akan kapasitas dan kapabilitas diri untuk secara profesional dapat mengungkapkan penyimpangan yang terjadi. Percaya diri tersebut dibentuk dengan cara mempelajari ilmu audit investigasi yang terus berkembang, memahami terlebih dahulu kasus dengan cara penelaahan informasi awal dan ekspose awal sebelum memulai penugasan, merencanakan prosedur audit sebaik mungkin, melaksanakan prosedur audit dan melakukan modifikasi yang diperlukan."

Kapasitas umum disebut sebagai "keterampilan" (misalnya, Bowles et al., 2001). Keterampilan dapat dikembangkan atau dipelajari sehingga kapabilitas auditor pada dasarnya tergantung pada waktu yang mereka investasikan dalam belajar dan mengembangkan kapabilitasnya.

Responden PT mengutarakan,

"Dalam penugasan audit investigasi, saya percaya diri dalam mencari bukti sendiri dan menilai tingkat relevansi, kompetensi, dan kecukupan bukti tersebut. Auditor 
juga memerlukan rasa percaya diri dalam berhadapan dan berinteraksi dengan orang lain."

Penerapan karakter ini dinyatakan juga oleh Hurtt et al. (2003) bahwa auditor memerlukan rasa percaya diri untuk dapat menilai bukti bukti audit, selain itu, percaya diri diperlukan oleh auditor untuk dapat berhadapan dengan berinteraksi dengan orang lain atau klien, termasuk juga beradu argumentasi dan mengambil tindakan audit yang diperlukan berdasarkan keraguan atau pertanyaan yang timbul dalam dirinya.

Reponden KT menuturkan,

"Saya percaya akan kapasitas dan kapabilitas diri saya dalam mengolah semua bukti untuk dijadikan dasar simpulan. Namun simpulan sementara yang diambil harus didiskusikan melalui ekspose dengan sesama auditor investigasi karena sudut pandang dan pengalaman setiap auditor berbeda beda. Hal ini bertujuan untuk melihat kasus secara utuh."

Tim audit memaparkan hasil simpulan sementara dalam ekspose internal yang berbentuk FGD. Ekspose ini dilakukan untuk memperoleh masukan dan keyakinan bahwa semua prosedur telah dilaksanakan. Auditor investigasi lain diluar tim audit menilai, memberikan pandangan dan pendapatnya mengenai simpulan sementara. Hasilnya menjadi bahan pertimbangan dalam proses audit maupun perbaikan terhadap simpulan audit.

Responden AT mengungkapkan,

"Saya percaya diri dalam tim karena bisa saling mengingatkan dan melengkapi sepanjang penugasan audit."

Auditor individu biasanya bekerja dalam tim dengan auditor pemimpin adalah orang yang bertanggung jawab dalam pengarahan, pengawasan dan kinerja anggotanya. Perilaku auditor pemimpin mempengaruhi secara langsung kualitas audit dan pelaporan audit. Auditor pemimpin biasanya memiliki tingkat pengetahuan dan pengalaman audit yang lebih tinggi serta memiliki pengaruh signifikan atas proses audit (Durue et al., 2011). Rasa percaya diri responden AT saat menerapkan skeptisisme profesional dalam mendeteksi kecurangan dibangun dalam tim dengan dukungan dari rekan auditor lainnya dan auditor pemimpin.

\section{Self determination}

Determinasi diri mengacu pada sikap individu yang membuat pilihan dan keputusan berdasarkan preferensi dan kepentingan sendiri untuk mengatur tindakan sendiri. Karakter ini menunjukkan kemampuan auditor dalam menentukan kecukupan informasi yang disajikan sebagai bukti sebelum mereka membuat keputusan audit (Hurtt, Eining, \& Plumlee 2010). Penerapan karakter self determination diuraikan berikut.

Responden PM mengutarakan, 


\begin{abstract}
"Saya mengumpulkan dan mengevaluasi bukti secara objektif untuk dijadikan dasar pengambilan simpulan. Simpulan sementara yang dibuat oleh tim audit dipaparkan melalui ekspose internal dengan auditor investigasi lainnya, direviu berjenjang oleh kepala bidang dan kepala kantor, dan diuji melalui quality assurance oleh Kedeputian Investigasi BPKP Pusat."
\end{abstract}

Penerapan karakter ini digambarkan sebagai salah satu unsur skeptis, yaitu pengumpulan dan pengevaluasian bukti secara objektif mendorong auditor untuk mempertimbangkan kompetensi dan kecukupan bukti. Dalam menentukan kecukupan bukti audit, auditor harus menerapkan pertimbangan keahliannya (due profesional care) secara profesional dan objektif. Dalam audit investigatif, jumlah bukti audit yang dikumpulkan tidak dapat menggunakan metode sampling melainkan harus terhadap keseluruhan populasi. Supervisi terhadap hasil audit dilakukan dengan reviu berjenjang untuk menjamin mutu audit.

Responden PT mengungkapkan,

"Saya memutuskan sendiri tingkat kecukupan bukti untuk pengambilan keputusan."

Pengambilan keputusan dilakukan dengan bebas tanpa kendali ataupun pengaruh dari luar. Sikap ini dijelaskan dalam ilmu filsafat sebagai penerapan skeptisisme yang meliputi otonomi diri seperti mengarahkan diri sendiri dan kemandirian moral.

Responden KT menyatakan,

"Bila dalam proses audit ditemukan informasi yang tidak konsisten maka saya memutuskan untuk melakukan pengujian lebih karena itu merupakan indikasi awal kecurangan."

Hal yang serupa dinyatakan oleh Kurtz (1992) bahwa orang yang skeptis akan mengidentifikasi kontradiksi dan kesalahan dalam bukti atau klaim dari orang lain. Bunge (1991) menambahkan dalam kondisi demikian, orang yang skeptis akan melakukan penyidikan tambahan untuk memperoleh bukti tambahan sampai dia secara pribadi puas.

Responden AT mengemukakan,

"Saya tidak mengandalkan pernyataan pihak lain dan tidak mudah dipengaruhi oleh keyakinan atau pendapat orang lain."

Tidak mengandalkan berarti tidak langsung menerima dan membenarkan pernyataan pihak lain. McGinn (1989) mencirikan skeptis dengan hal yang serupa yaitu tidak mudah menerima klaim dari pihak lain. Penerapan karakter ini juga diidentifikasi oleh Quadackers et al. (2014) bahwa auditor dengan tingkat skeptisisme profesional yang tinggi akan kurang mengandalkan penjelasan klien. Hal yang senada dinyatakan oleh Hurtt et al. (2010) bahwa auditor yang skeptis fokus pada determinasi dirinya sendiri mengenai kebenaran suatu pernyataan dan kurang dipengaruhi oleh keyakinan atau upaya persuasi dari orang lain. 


\section{SIMPULAN, KETERBATASAN DAN SARAN}

Kesimpulan dari hasil penelitian ini adalah auditor investigasi Perwakilan BPKP Provinsi Jawa Tengah memiliki pemahaman yang memadai terkait skeptisisme profesional dan menerapkan skeptisisme profesional dalam mendeteksi kecurangan sesuai karakteristik yang dikembangkan oleh Hurtt et al. (2010). Pemahaman auditor investigasi telah sesuai dengan konsep yang dinyatakan oleh para ahli dan peraturan audit baik nasional maupun internasional. Penerapan skeptisisme profesional juga telah sesuai dengan pedoman audit, standar audit, dan hasil penelitian para ahli.

Sampai dengan saat ini Perwakilan BPKP Jawa Tengah telah menerima sejumlah enam gugatan terhadap hasil auditnya. Hal tersebut wajar dikarenakan peluang adanya gugatan terhadap hasil audit akan selalu ada. Berikut uraian alasan penerimaan gugatan. Pertama, UUD 1945 pasal 27 ayat (1) berbunyi, "Segala warga negara bersamaan kedudukannya di dalam hukum dan pemerintahan dan wajib menjunjung hukum dan pemerintahan itu dengan tidak ada kecualinya". Pasal ini menjelaskan persamaan di muka hukum (equality before the law) bahwa setiap warga negara sama di hadapan hukum dan haknya diberikan tanpa diskriminasi untuk mendapatkan perlindungan hukum yang sama. Demikian juga halnya hak untuk melakukan upaya hukum dalam melawan atau menggugat hak konstitusional warga negara tersebut. Upaya hukum dimaksud dapat dilakukan terhadap keputusan administrasi negara, ketentuan pengaturan, dan terhadap putusan hakim (vonnis) dengan cara mengajukannya ke lembaga pengadilan yang lebih tinggi, yaitu tingkat banding, kasasi, atau peninjauan kembali. Ketika terdakwa merasa dirugikan haknya atau keberatan terhadap hasil audit BPKP, maka terdakwa menggugat BPKP.

Kedua, Ketentuan Pasal 2 ayat (1) Jo Pasal 18 Undang-undang Nomor 31 Tahun 1999 Tentang Pemberantasan Tindak Pidana Korupsi Jo Undang-undang Nomor 20 Tahun 2001 Tentang Perubahan Atas Undang-undang Nomor 31 Tahun 1999 Tentang Pemberantasan Tindak Pidana Korupsi merumuskan "Setiap orang yang secara melawan hukum melakukan perbuatan memperkaya diri sendiri atau orang lain atau suatu korporasi yang dapat merugikan keuangan negara atau perekonomian negara dipidana dengan penjara seumur hidup atau pidana penjara paling singkat 4 (empat) tahun dan paling lama 20 (dua puluh) tahun dan denda paling sedikit Rp200.000.000,00 (dua ratus juta rupiah) dan paling banyak Rp1.000.000.000,00 (satu milyar rupiah)". Salah satu unsurnya ialah dapat merugikan keuangan negara dengan perhitungan kerugian keuangan negara dilakukan oleh BPKP. Jika unsur tersebut gugur maka tindak pidana korupsi tidak terbukti. Oleh sebab itu terdakwa berusaha mengugurkan laporan audit Perhitungan Kerugian Keuangan Negara (PKKN) dengan cara menggugat BPKP ke Pengadilan Tata Usaha Negara (PTUN). 
Keputusan PTUN yaitu sejumlah lima gugatan terhadap Perwakilan BPKP Provinsi Jawa Tengah ditolak dan satu gugatan masih dalam proses pengadilan. Hasil ini menunjukkan bahwa BPKP mampu mempertanggungjawabkan kebenaran laporan hasil auditnya. Auditor BPKP telah melakukan seluruh prosedur audit dengan benar dan memenuhi standar audit, salah satunya standar umum ketiga terkait kewajiban auditor menggunakan kemahiran profesionalnya dengan cermat dan seksama termasuk skeptisisme profesional. Dengan skeptisisme profesional, auditor berhasil mengungkapkan kecurangan yang terjadi di pemerintahan.

\section{DAFTAR PUSTAKA}

(ASB), Auditing Standards Boards. 2011. "Responsibilities and functions of the independent auditor." New York: ASB.

(IAASB), International Auditing and Assurance Standards Board. 2012. "Professional skepticism in an audit of financial statements. IAASB staff questions and answers." New York, NY.

(PCAOB), Public Company Accounting Oversight Board. 2011. "Concept release on auditor independence and auditor firm rotation. Release No. 2011-006." Washington, DC: PCAOB.

Anggriawan, E. 2014. "Pengaruh pengalaman kerja, skeptisisme profesional, dan tekanan waktu terhadap kemampuan mendeteksi fraud." Jurnal Nominal 3 (2): 30-36.

Askary, S, D. Goodwin, dan R. Lanis. 2012. "Improvements in audit risks related to information technology frauds." International Journal of Enterprise Information Systems 8 (2): 52-63.

Bailey, T. C, W.M. Eng, B. Frisch, dan C. R. Snyder. 2007. "Hope and optimism as related to life satisfaction." The Journal of Positive Psychology 2 (3): 168-75.

Beasley, S, Joseph V. Carcello, dan Dana R. Hermanson. 2001. "Fraud related sec enforcement against auditors." Journal of Accountancy 191 (4): 63-66.

Boush, D. M, M. Friestad, dan G. M. Rose. 1994. "Adolescent skepticism toward TV advertising and knowledge of advertiser tactics." The Journal of Consumer Research 21 (1): 165-75.

Bowles, S., H. Gintis, dan M. Osborne. 2001. "The determinants of earnings: a behavioral approach.” Journal of Economic Literature 39 (4): 1137-76.

Bunge, M. 1991. “A skeptic's beliefs and disbeliefs.” New Ideas in Psychology 9 (2): $131-49$.

Castro, G. S. 2013. "Internal auditor skeptisism in detecting fraud: A quantitative 
study." Social Science Research Network, 118.

Cohen, J. R, D. W. Dalton, dan L. N. Harp. 2014. "The effect of professional skepticism on job attitudes and turnover intentions within the audit profession (March 17)."

Durue, D. S., J. D. Nahrgang, N. Wellman, dan S. E. Humphrey. 2011. "Trait and behavioral theories of leadership; an integration and meta-analytic test of their relative validity." Personell Psychology 64: 7-52.

Fogelin, Robert J. 1994. Pyrrhonian reflections on knowledge and justification. New York: Oxford University Press.

Fullerton, Rosemary, dan Cindy Durtschi. 2005. "The effect of profesional skeptisism on the fraud."

Gusti, M., dan S. Ali. 2008. "Hubungan skeptisisme profesional auditor dan situasi audit, etika, pengalaman serta keahlian audit dengan ketepatan pemberian opini auditor oleh akuntan publik."

Guthrie, J., C. Humphrey, L. R. Jones, dan O. Olson. 2005. International public financial management reform, progress, contradictions, and challenges. Connecticut: Information Age Publishing.

Hallie, Philip Paul. 1985. Sextus empiricus: selections from the major writings on skepticism, man, and god. Indianapolis, IN: Hackett Publishing Company.

Helmreich, R., J. T. Spence, dan J. Stapp. 1974. "Short form of the texas social behavior inventory, an objective measure of self-esteem." Bulletin of the Psychonomic Society 4: 473-75.

Hurtt, R. Kathy, Martha M. Eining, dan David Plumlee. 2003. "Professional scepticism: A model with implications for research, practice, and education." United States.

—. 2008. "An experimental examination of profesional skeptisism." Baylor University, United States.

- 2010. "Development of a scale to measure profesional skeptisism." Auditing: A Journal of Practice and Theory 29: 149-171.

Kurtz, P. 1992. The new skeptisism: inquiry and reliable knowledge. New York: Promotheus Book.

Louwers, Timothy J. 2005. Auditing and assurance service. Pennsylvania State University: McGraw-Hill.

Martin, R. D., dan F. Phillips. 2006. "Aeroscape lighting, inc: linking business strategy to audit planning." Issues in Accounting Education 21 (3): 313-321.

Mautz, R.K., dan H.A. Sharaf. 1961. The philosophy of auditing. Sarasota, Florida: 
American Accounting Association.

McGinn, Marie. 1989. Sense and certainty: a dissolution of scepticism. New York, NY: Basil Blackwell, Inc.

Peterson, B., dan T. A. Buckhoff. 2004. "Interstate business college: a case study in fraud examination." Issues in Accounting Education 19 (4): 505-27.

Popova, V. 2013. "Exploration of skepticism, client-specific experiences, and audit judgments." Managerial Auditing Journal 28 (2): 140-160.

Pramudyastuti, L. 2014. "Pengaruh skeptisisme profesional, pelatihan audit kecurangan, dan independensi terhadap kemampuan auditor dalam mendeteksi kecurangan (studi di inspektorat kabupaten sleman)." Universitas Gajah Mada Yogyakarta.

Quadackers, L, T. Groot, dan A. Wright. 2014. "Auditors' professional skepticism: neutrality versus presumptive doubt." Contemporary Accounting Research 31 (3): 639-57.

Quadackers, Luc, Tom Groot, dan A. Wright. 2009. "Auditors' skeptical characteristics and their relationship to skeptical judgments and decisions." United States: Northeastern University.

Saksena, P. N. 2008. "Four tools (under the umbrella of continuous improvement) to help auditors prevent/detect frauds." Allied Academies International Conference: Proceedings of the Academy of Accounting \& Financial Studies (AAFS) 13 (2): 27-30.

Shaub, M. K., dan J. E. Lawrence. 1996. "Ethics, experience, and profesional skepticism: a situational analysis." Behavioral Research in Accounting Supplement, 124-57.

Shleifer, A., dan R. W. Vishny. 1993. "Corruption." The Quarterly Journal of Economics 108 (3): 599-617.

Stough, Charlotte L. 1969. Greek skepticism. Berkeley, CA: University of California Press, Ltd. https://doi.org/10.2307/2024797.

Tuanakotta, Theodorus M. 2012. Akuntansi forensik dan audit investigatif. Jakarta: Salemba Empat. . 2013. Berpikir kritis dalam auditing. Jakarta: Salemba Empat. 